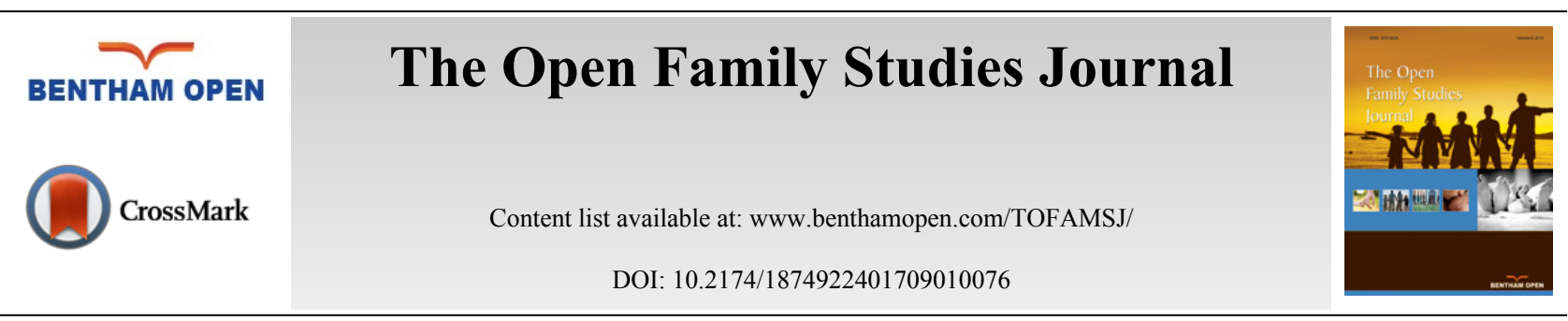

RESEARCH ARTICLE

\title{
Language and Psychosocial Skills of Institutionalized Children in Greece
}

\author{
Ralli, M. Asimina ${ }^{1, *}$, Schiza Melpomeni ${ }^{2}$ and Tsiatsiou Alexandra ${ }^{1}$ \\ ${ }^{I}$ Department of Psychology, Faculty of Philosophy, Pedagogy and Psychology, National and Kapodistrian University of \\ Athens, Athens, Greece \\ ${ }^{2}$ Early Childhood Department, Technological Educational Institution of Athens, Athens, Greece
}

Received: January 17, 2017

Revised: April 24, 2017

Accepted: June 14, 2017

\begin{abstract}
:
Background:

Institutionalization is increasingly acknowledged as a poor policy for the children. Every country has important responsibilities concerning the protection and promotion of children's rights who are already in alternative care. Even a relatively short institutional placement may have long term negative consequences on children's well-being and adult life.
\end{abstract}

Aim:

The aim of the present study was to investigate the language and psychosocial skills of Greek institutionalized children in comparison to family raised children.

\section{Method:}

60 preschool children (30 institutionalized children and 30 children brought up in families) participated in the study. The children ranged in age from 4 to 5 years of age. Children's language and psychosocial skills were assessed.

\section{Result:}

The results demonstrated that the institutionalized children had significantly lower scores in the expressive, receptive vocabulary, narrative skills and psychosocial adjustment in comparison to the children raised in families. These results are discussed in relation to their implications for policy makers in order to move towards the development of new policies, where children are taken care of in more supportive surroundings than an institution.

Keywords: Institutionalization, Preschool children, Language skills, Psychosocial skills.

\section{INTRODUCTION}

Although it is widely accepted that institutional care is linked to unfavorable results in children's development [1, 2], youngsters are frequently placed in such institutions throughout the world. According to the results of a world-wide investigation which was carried out within 47 countries under the guidance of the World Health Organization (WHO) Regional Office for Europe, an estimated number of 43,842 (14.4 per 10,000) children under the age of three, lived in residential care homes without a parent for a period of more than three months [3]. Carter [1] claims that exaggerated use of institutional care for children is much more common than official statistics advocate. Further observations indicated that institutional care is on rise in countries facing economic change, since for a large number of families and

\footnotetext{
* Address correspondence to this author at the Department of Psychology, Faculty of Philosophy, Pedagogy and Psychology, National and Kapodistrian University of Athens, Athens, Greece; Tel: +210 7277945; E-mails: asiminaralli@gmail.com, asralli@psych.uoa.gr
} 
communities the transition has led to an increase in unemployment, migration for work, family disintegration and single parenthood $[1,4]$.

Looking at Romania the main reason given for a child's abandonment is poverty [5]. Lumos [6], a global nongovernmental philanthropic organisation which is devoted in bringing about major changes in the lives of disadvantaged children who live in institutions around the world, has reported that an estimated number of 3,000 youngsters and teenagers, including children with special needs, live in approximately 85 private and state funded residential institutions in Greece. Lumos's study about the Greek children who live in institutions, confirms that except for poverty, lack of parental skills, parents with special needs, poor education, illnesses or inadequate housing were as important factors for children to be placed in an institution. Therefore, the fact that institutionalised children are characterised by a lot of developmental difficulties due to genetic risk factors, limited early experiences in their families as well as poor conditions existing in the institutions they lived [7].

\subsection{Language and Psychosocial Development of Institutionalized Children}

Johnson et al. [2] after conducting a systematic literature review came to the conclusion that 2,624 articles exist on early deprivation of parenting or children in residential care published in English from 1944 to 2003. Seventeen studies out of the twenty seven examined social and behavioural problems that were common among children who had been raised in institutions. Fifty six children had been adopted from Russia, Moldova, Ukraine, Albania, Kazakhstan, Latvia, Poland, and Bulgaria and were examined by Albers, Johnson, Hostetter, Iverson, and Miller [8]. These children demonstrated one month delayed growth, for every five months they had lived in the institution.

Judge [9] found that developmental recovery of the Eastern European adoptees was not anticipated by height or weight when adoption took place, suggesting that post-adoption development was not part of malnourishment or stunted growth. Physical challenges were often resolved within the first few years after adoption [10].

Institutions raising deserted or orphaned children are usually characterised by rotating shifts of numerous caregivers, restrained language input, limited social and intellectual stimulation, and disproportionate child-to-caregiver proportions $[11,5]$. Some children who go through extraordinary hardship exhibit behaviour which often includes swaying back and forth, self-harm and abnormal sensory interests, behaviours, usually seen in autistic spectrum disorder [3, 13, 14]. For children brought up in organizations, that type of behaviour may reflect a self-calming capacity or adjustment to the institution environment [15]. Maclean [16], describing typical life of young children in institutions claimed that they spend a large part of their daily routine in a crib with «an empty gaze» or tapping on the crib/cot bars.

An early report by Goldfarb [17] demonstrated that 9 in 15 youngsters living in an orphanage in the United States were not able to perceive everyday objects. A subsequent study by Provence and Lipton [18] assessed 75 institutionalized children, during their first years of life. Children's chances for social co-operation were depicted as weak and sporadic, largely taking place, during every day routines, such as washing, and nourishing times. The researchers also found that the newborn children's vocalizations were less complex and remarkably less recurrent, with some babies even being completely non-vocal. Newborn children's comprehension abilities also appeared to be undeveloped. Dubrovima [19] found that $60 \%$ of orphanage residing children between the ages of 2 to 2, 5 years old were not able to speak. The following year, only $14 \%$ of the children were using phrases consisting of two words (telegraphic speech). By 3 to 4 years old the youngsters were reported to possess poor command of language specifically limited word use, responsive language delays and incoherent discourse.

Glennen [20] observed a group of ten Russian toddlers in an orphanage. Two of the oldest toddlers, uttered just one word, while the other toddlers did not speak at all. What raised most concern was the low recurrence of any informative vocalizations, including babbling. Aside from incidental cries, the children were quiet during their interchanges. The children had been distributed in groups according to their age and potential. Only once in a while they were permitted to play or come in contact with older children who may have filled as dialect models. When children were carried, they faced outwards, with their heads turned away from the caregiver. When children were spoken to, it was ordinarily in the form of basic instructions like «come here». «Sit down», «don't do that». Over the 8 days of visits, there were only $3-4$ cases of communication that were observed, where caregivers interpreted objects, actions, or presented other forms of «language instruction» experiences. Also, according to Judge [9] just 14\% of children made use of basic phrases consisting of two words among 3 year old children living in Moscow institutions.

Windsor, Glaze, Koga, and the BEIP Core Group [21] recorded language results from 40 children within a group consisting of 158 participants. From the whole group of the 40 children, 10 of them had lived all their lives in 
institutional care, 10 children had moved from orphanages to foster care in the recent past, 10 of them had moved from orphanages to foster care for one year at least and 10 children had grown up living with their biological families. Children who were institutionalized and children in foster care for a short period of time demonstrated significant delays in language, with some of them not even being able to utter comprehensible words. Children in foster care for no less than one year approximated the expressive output and receptive language of children who had never been placed in foster care; nevertheless, they demonstrated reduced articulation and linguistic skills. It was also found that the institutionalized children, who were attached to a caregiver, had both an increased height, as well as better language skills, in comparison to the institutionalized children who were not attached to a caregiver.

In spite of the fact that children in institutions produced less elaborate language structures than those brought up in biological families, there were no qualitative disparities in language structure across the groups.

More recently Windsor et al. [22] examined 174 children's (institutionalized, in foster families, none institutionalized) language outcomes in the Bucharest Early Intervention Project. According to the results, foster care influenced positively children's language skills. Children placed in foster care by the age of two exhibited enriched language outcomes between 2, 5 and 3,5 years old. Children receiving foster care at a later developmental stage exhibited remarkably serious expressive and receptive setbacks, equivalent to those of children residing in institutions. Both of these groups made use of single words and phrases generally.

Furthermore, institutional care drastically expands the danger for psychosocial challenges along with positive incitement, social connection and relationship problems, disturbing contact issues, sensitivity to social limits, formulation and preservation of intimacy as well as emotional adjustment and control [13, 23 - 26]. While some of the institutions might provide the essential incentive to cover some of the children's cognitive, motor, and language needs, none of the institutions which had previously been studied had met infants' needs for social relationships properly (for example their need for secure attachments and steady relationships which can contribute to a well-adjusted personality in adulthood [27].

Smyke et al. [11] examined the attachment behavior in an orphanage in Bucharest, where typical institutional care was basically composed of 20 different caregivers, with 3 caregivers assigned to a group of 30 children on each shift. Apart from children who received standard care they also examined a group of children who received care with a higher caregiver to-child proportion (4 steady caregivers). Almost all of the children in the higher caregiver proportion background had identified a particular caregiver with whom they had a selective attachment. Therefore, these children had received a greater social and language input than would have been the case for children for whom favoured caregivers were not identified.

Institutionalized children are usually characterised by a difficulty to maintain social boundaries. This particular behaviour arrangement has been defined as indiscriminate friendliness [28]. Indiscriminately friendly children react in too intimate ways towards unknown strangers, without showing typical fear or reticence [29]. In Tizard's study of youngsters placed in residential crèches in London in the 1960s [30, 31], 38.4\% of the institutional children residing in institutions were indiscriminately friendly at 4 years of age. More specifically they were approaching and asking attention from relative strangers just as willingly as from familiar caregivers. More than half of the children under observation in a Bucharest institution generally presented disinhibited social approach behaviours [32].

Smyke et al. [11] observed an inverted U pattern of aggression among young children in the institution, in which they were demonstrating either very high or very low levels of aggression. This pattern was contrary to that of children raised in families who displayed moderate aggression levels.

\subsection{Long Term Effects of Institutionalization}

Age of adoption as well as duration of institutionalization has generally been found to be important contributors to later outcomes. Beckett et al. [33] discovered that children who had been institutionalized over 6 months showed decreased cognitive functioning than children who had been institutionalized less than 6 months. Croft et al. [34] also inspected the long-term English language test results for Romanian children adopted into the UK. In assessments of the children's oral skills at 6 years and reading comprehension at 11 years of age, children who had lived in institutional care for over 6 months demonstrated very significant language problems.However, less negative effects were noted for those who had experienced fewer than 6 months of institutional care.

Also, dos Reis et al. [35] found higher percentages of mental health assistance use among children on Medicaid because they were in foster care $(62 \%)$, in comparison with groups receiving Medicaid because of physical, or 
psychological disability (29\%) or poverty (4\%). Fostered children had increased rates of attention-deficit hyperactivity disorder (ADHD), depression and adjustment disorders compared with the other groups. A substantial delay in maturation of the cortex was found among children with ADHD, compared to children without the disorder [36, 37].

\subsection{The Situation in the Greek Context}

Although in Greece there are limited studies in the specific area, there is a group of researchers who have worked on the specific domain for many years, focusing mainly on the psychosocial skills of institutionalised children. For example, Vorria and her colleagues [38] observed infant-caregiver relationships using the Ainsworth Strange Situation paradigm. Specifically they studied the attachment relationships of 86 infants raised in a residential group care and 41 infants raised in their own nuclear families.

The findings indicated that a high percentage $(66 \%)$ of the infants raised up in a residential group care, when observed with their most familiar caregivers, showed disordered patterns of attachment, compared to a $25 \%$ of infants (control group) who had been raised in their own family environment. Only 24\% of group care infants were securely attached compared with $41 \%$ of control group infants.

Greek infants living in a Babies' Center including the control group infants were observed again in a consequent study at the age of four after at least two years of living with their adopted families, while the control group stayed with their birth families [39]. At four years old adopted children still scored poorly on cognitive tasks, exhibited insecurity, and were less able to understand emotions compared with family raised children. Children with a secure attachment type in babyhood were found to be less secure at age four, in comparison with those who were classified in infancy as having an insecure attachment type. Their physical development was back on track, they were less timid, had no behavioral issues at school.

In a follow up study, Vorria and her colleagues [40] investigated the rate of disorganization on attachment qualities in adolescence among fifty two adopted adolescents for whom the same Babies' Centre had been home for their first two years of life and thirty six adolescents raised up with their biological families. They found a significant drop in the rate of disorganization and a lack of a significant difference between the formerly institutionalized group and the family care comparison group on attachment qualities in adolescence.

Another Greek study [41] examined the formation of attachment relationships between infants residing in the same Babies' Centre and their substitute mothers. The researchers claimed that the infants who had been raised in a residential group care, even in a polymatric institution, with a number of caregivers, were able to develop selective attachments with them. They also reported that even 7-9 months old infants were attached to adults and were able to bond with a new figure. Indeed they suggested that due to the fact they were attached to adults in the same Babies' Centre, none of the negative consequences (e.g., depression, marasmus, detachment, indiscriminate attention seeking) of institutionalization were observed. In another study Giagazoglou et al. [42], investigated the psychomotor development of three groups of children living in conventional institution facilities, in another well known institution in Greece1 [43] and with their families. The family reared children were able to perform all tasks, in the six scales Griffiths test at an earlier age [44] with the highest score being noted in the speech and hearing scale, in comparison to the other two groups of children.

It appears that, although there is a group of studies investigating the effects of institutionalization in Greece, still there are limited data concerning the effects of institutionalization in preschool children's language and psychosocial development. This present study aims to examine the language and psychosocial skills of Greek institutionalised children, aged 5-6 years old in comparison to children living with their families. We hypothesized that children raised in institutions would exhibit lower performance in language and psychosocial skills in comparison to the family raised children.

\section{METHOD}

\subsection{Participants}

The sample in Table 1 was composed of 60 children between the ages of 4-5 years, thirty living in an institution and thirty

${ }^{1}$ This well known institution represent a global operation that has sought to provide housing and family oriented child care to orphaned or abandoned children since 1949. This institution encourages the free development of the individual personality and aptitude of every child and is based on four 
principles: a) The mother: Each homeless child is provided with a mother to help it learn the meaning of love and security, not just an educator; b) Siblings: Every «family» is made up of six to eight children who live with their «mother» like a regular family; c) The house: The house is a permanent home and the children feel protected within its walls; d) The village: The village consists of 12 to 15 family homes and is believed to be the bridge assimilating the children into society.

brought up in families. Among institutionalized children fifteen were boys and fifteen were girls, and the same ratios were evident for the children living with families.

Table 1. Description of the sample.

\begin{tabular}{|c|c|c|c|}
\hline Sample & Male & Female & Total \\
\hline Institution & 15 & 15 & 30 \\
Family & 15 & 15 & 30 \\
Total & 30 & 30 & 60 \\
\hline
\end{tabular}

\subsection{Measures}

Children's language and psychosocial skills were assessed through a series of standardised psychometric tests. In order to assess children's language skills a set of the following tests were used: (a) The Word Finding Vocabulary Test (Vogindroukas, Protopappas, \& Sideridis, 2007) and (b) The Assessment for the Identification of Disorders of Speech and Language in Preschool Children (Economou, Besevegis, Mylonas, \& Varlokosta 2007).

The Word Finding Vocabulary Test is a standardised language test which aims to measure language skills of 4 to 8 years old children. It contains 50 line-drawn pictures of familiar objects and daily life images. It assesses the extent to which these pictures can be named correctly. Each correct answer is given one point and no points are given for each wrong answer.

The Assessment for the identification of disorders of speech and language in preschool children consists of a naming task (expressive vocabulary) a comprehension task (receptive vocabulary) and a narrative task. In the naming task the children were asked to name pictures of objects, in the comprehension task children were invited to see a set of four pictures and then to point at the one that the experimenter asked them to point. In the narrative task the children were given a set of six pictures and were asked to tell a story according to them. The narrative was recorded and then was evaluated according to certain criteria (vocabulary, syntax, morphological errors and narrative content).

The criterion of Vocabulary refers to (a) the total amount of the words, (b) the total amount of sentences, (c) the total amount of utterances and (d) the narrative verbal flow. The narrative verbal flow refers to the number of the produced words every minute. It also includes the mean length of the utterance which is equal to the ratio of the total number of the words divided by the total number of the narrative utterances.

Syntax refers to the number of the sentences with coordinating conjunctions, the sentences with subordinating conjunctions, clitic doubling constructions /use of participles. Finally, it refers to the total of the syntactic structures which is the sum of the above-mentioned syntactic structures.

Regarding the morphological errors the examiner evaluated the rate at which articles, pronouns and nouns were absent and also the rate at which errors with nouns, agreement errors in nominal phrases, errors in tense, aspect, voice, mood, errors in subject-verb agreement and errors with prepositions occurred. The total score of the morphological errors is the sum of the above-mentioned errors.

Regarding the narrative content, the theme of the story and the degree to which there is a link between the cards are evaluated. The evaluation of the theme is based on the use of the proper nouns and the verbal sentences in children's narratives. The use of specific nouns gets one point or zero points. The highest score for each card is 4 points for the use of the correct nouns and 2 points for the use of the correct verbal sentences. The child can get from zero to 28 points for the correct nouns and zero to 14 points for the correct verbal sentences he/she used in his /her story. If there's a link between the cards the child gets one or two points. Specifically the examinee gets zero points if there is no link, one point if the link isn't obvious but there is a sequence of the events in the story and two points if the sequence of the events of the story is satisfying.

The Scale of Psychosocial Adjustment for preschool and school children (Hatzichristou, Polychroni, Besevegis, \& Mylonas, 2007) was used to evaluate children's psychosocial skills. The scale includes questions about Social Competence (Assertion Skills, Interpersonal Communication and Peer Cooperation), School Competence (Motives, Planning and Organizational Skills and School Effectiveness and School Adjustment), Emotional Competence (Self- 
Management, Emotion Management, Stress Management and Empathy) and Behavior Problems (Interpersonal Adjustment, Intrapersonal Adjustment and Hyperactivity). Data were scored in a 5-point Likert scale.

\subsection{Procedure}

Language tests took place in a quiet place either in the institution or in the nursery school. The total duration of assessment was approximately 30 minutes for every child. Before the assessment, the examiner tried to create an interpersonal climate and make children feel comfortable and follow the given instructions. Institutionalised children's caregivers and family raised children's nursery teachers were asked to complete the psychosocial scale, once consent was signed by both sides.

\section{RESULTS}

\subsection{Children's Performance in the Language Tests}

The first research question was whether the language skills of institutionalised children differ in comparison to their counterparts living with their families. According to Table $\mathbf{2}$ the institutionalized children had statistically significant lower scores in comparison to the children living with their families across all language measures: Expressive Vocabulary $(\mathrm{t}=-8.051, \mathrm{p}=.000)$, Vocabulary Comprehension $(\mathrm{t}=-7.888, \mathrm{p}=.000)$, Narrative task (Number of Words: $\mathrm{t}=-6.707, \mathrm{p}=.000$, Number of Sentences: $\mathrm{t}=-2.632, \mathrm{p}=.011$, Number of Utterances: $\mathrm{t}=-6.233, \mathrm{p}=.000$, Mean Length of Utterance: $\mathrm{t}=-3.924, \mathrm{p}=.000$, Narration Verbal Flow: $\mathrm{t}=-3.038, \mathrm{p}=.004$, Number of Nouns: $\mathrm{t}=-5.350, \mathrm{p}=.000$, Number of Verbal Sentences: $\mathrm{t}=-5.219, \mathrm{p}=.000$ ), Total of Narrative Structure: $\mathrm{t}=-5.478, \mathrm{p}=.000)$. No gender differences were evident.

Table 2. Children's Performances on Language tasks.

\begin{tabular}{|c|c|c|c|c|}
\hline Language Measures & Groups & $n$ & Mean & $S D$ \\
\hline Expressive Vocabulary & $\begin{array}{c}\text { Institution } \\
\text { Family }\end{array}$ & $\begin{array}{l}30 \\
30\end{array}$ & $\begin{array}{l}26.27 \\
33.27\end{array}$ & $\begin{array}{l}2.2 \\
4.2\end{array}$ \\
\hline Vocabulary Comprehension & $\begin{array}{c}\text { Institution } \\
\text { Family }\end{array}$ & $\begin{array}{l}30 \\
30\end{array}$ & $\begin{array}{l}10.50 \\
13.13\end{array}$ & $\begin{array}{c}1.5 \\
.9\end{array}$ \\
\hline \multicolumn{5}{|l|}{ Narrative Task } \\
\hline Number of Words & $\begin{array}{c}\text { Institution } \\
\text { Family }\end{array}$ & $\begin{array}{l}30 \\
30\end{array}$ & $\begin{array}{c}55.10 \\
106.77\end{array}$ & $\begin{array}{l}25.8 \\
33.3\end{array}$ \\
\hline Number of Sentences & $\begin{array}{c}\text { Institution } \\
\text { Family }\end{array}$ & $\begin{array}{l}30 \\
30\end{array}$ & $\begin{array}{l}12.47 \\
15.83\end{array}$ & $\begin{array}{l}6.1 \\
3.4\end{array}$ \\
\hline Number of Utterances & $\begin{array}{c}\text { Institution } \\
\text { Family }\end{array}$ & $\begin{array}{l}30 \\
30\end{array}$ & $\begin{array}{l}14.80 \\
25.80\end{array}$ & $\begin{array}{l}5.2 \\
8.1\end{array}$ \\
\hline Mean Length of Utterance & $\begin{array}{c}\text { Institution } \\
\text { Family }\end{array}$ & $\begin{array}{l}30 \\
30\end{array}$ & $\begin{array}{l}3.41 \\
4.53\end{array}$ & $\begin{array}{c}.9 \\
1.2\end{array}$ \\
\hline Narration Verbal Flow & $\begin{array}{c}\text { Institution } \\
\text { Family }\end{array}$ & $\begin{array}{l}30 \\
30\end{array}$ & $\begin{array}{l}22.764 \\
38.790\end{array}$ & $\begin{array}{l}25.7 \\
13.1\end{array}$ \\
\hline Number of Nouns & $\begin{array}{c}\text { Institution } \\
\text { Family }\end{array}$ & $\begin{array}{l}30 \\
30\end{array}$ & $\begin{array}{l}13.27 \\
20.83\end{array}$ & $\begin{array}{l}5.5 \\
5.4\end{array}$ \\
\hline Number of Verbal Sentences & $\begin{array}{c}\text { Institution } \\
\text { Family }\end{array}$ & $\begin{array}{l}30 \\
30\end{array}$ & $\begin{array}{c}6.57 \\
10.27\end{array}$ & $\begin{array}{l}3.0 \\
2.4\end{array}$ \\
\hline Total of Narrative Structure & $\begin{array}{c}\text { Institution } \\
\text { Family }\end{array}$ & $\begin{array}{l}30 \\
30\end{array}$ & $\begin{array}{l}13.70 \\
20.70\end{array}$ & $\begin{array}{l}6.4 \\
2.7\end{array}$ \\
\hline
\end{tabular}

The qualitative analysis of children's narratives demonstrated that the institutionalized children made more morphological errors (e.g. errors with nouns, verbs, pronouns, tenses, absence of articles, pronouns) in comparison to the children raised with families. Also, the narratives of the institutionalized children were characterized by simpler syntactic structures without using e.g. subordinate clauses, subordinating conjunctions, adjective clauses, adverb clauses, etc.

\subsection{Children's Performance in the Psychosocial Skills}

The second research question addressed, concerned the psychosocial skills of institutionalised children and children living with their families. As can be seen in Table 3, children in families had statistically significant higher scores in 
psychosocial skills in comparison with children living in institutions. More specifically, the institutionalized children had statistically significant lower scores than children raised up in families in Social Competence: $\mathrm{t}=-4.153, \mathrm{p}=.000$ (Assertion Skills: $\mathrm{t}=-.072, \mathrm{p}=.943$, Interpersonal Communication: $\mathrm{t}=-5.155, \mathrm{p}=.000$, Peer Cooperation: $\mathrm{t}=-5.205, \mathrm{p}=$ $.000)$, School Competence: $\mathrm{t}=-9.381, \mathrm{p}=.000$ (Motives: $\mathrm{t}=-7.191, \mathrm{p}=.000$, Planning and Organizational Skills: $\mathrm{t}=$ -9.643, $\mathrm{p}=.000$, School Effectiveness: $\mathrm{t}=-7.475, \mathrm{p}=.000$, School Adjustment: $\mathrm{t}=-7.693, \mathrm{p}=.000)$, Emotional Competence: $\mathrm{t}=-7.414, \mathrm{p}=.000,($ Self-Management $: \mathrm{t}=-8.995, \mathrm{p}=.000$, Emotion Management: $\mathrm{t}=-3.992, \mathrm{p}=.000$, Stress Management: $\mathrm{t}=-3.244, \mathrm{p}=.002$, Empathy: $\mathrm{t}=-.072, \mathrm{p}=.943$ ) and Behavior Problems: $\mathrm{t}=9.833, \mathrm{p}=.000$ (Interpersonal Adjustment: $\mathrm{t}=-.254, \mathrm{p}=.801$, Intrapersonal Adjustment: $\mathrm{t}=-.929, \mathrm{p}=.357$, Hyperactivity: $\mathrm{t}=7.428, \mathrm{p}=$ $.000)$.

Table 3. Children's Performances on Psychosocial Adjustment by group.

\begin{tabular}{|c|c|c|c|c|}
\hline Psychosocial Adjustment & Groups & $n$ & Mean & $S D$ \\
\hline Social Competence & $\begin{array}{c}\text { Institution } \\
\text { Family }\end{array}$ & $\begin{array}{l}30 \\
30\end{array}$ & $\begin{array}{l}53.03 \\
68.60 \\
\end{array}$ & $\begin{array}{c}18.2 \\
9.3\end{array}$ \\
\hline Assertion Skills & $\begin{array}{c}\text { Institution } \\
\text { Family }\end{array}$ & $\begin{array}{l}30 \\
30\end{array}$ & $\begin{array}{l}11.20 \\
11.27\end{array}$ & $\begin{array}{l}4.1 \\
2.8\end{array}$ \\
\hline Interpersonal Communication & $\begin{array}{c}\text { Institution } \\
\text { Family }\end{array}$ & $\begin{array}{l}30 \\
30\end{array}$ & $\begin{array}{l}29.93 \\
41.43\end{array}$ & $\begin{array}{c}11.0 \\
5.2\end{array}$ \\
\hline Peer Cooperation & $\begin{array}{c}\text { Institution } \\
\text { Family }\end{array}$ & $\begin{array}{l}30 \\
30\end{array}$ & $\begin{array}{l}11.57 \\
16.17\end{array}$ & $\begin{array}{l}4.1 \\
2.5\end{array}$ \\
\hline School Competence & $\begin{array}{c}\text { Institution } \\
\text { Family }\end{array}$ & $\begin{array}{l}30 \\
30\end{array}$ & $\begin{array}{c}68.83 \\
100.67\end{array}$ & $\begin{array}{l}13.1 \\
13.1\end{array}$ \\
\hline Motives & $\begin{array}{c}\text { Institution } \\
\text { Family }\end{array}$ & $\begin{array}{l}30 \\
30\end{array}$ & $\begin{array}{l}10.33 \\
15.03\end{array}$ & $\begin{array}{l}2.2 \\
2.7\end{array}$ \\
\hline Planning and Organizational Skills & $\begin{array}{c}\text { Institution } \\
\text { Family }\end{array}$ & $\begin{array}{l}30 \\
30 \\
\end{array}$ & $\begin{array}{l}33.00 \\
48.07 \\
\end{array}$ & $\begin{array}{l}5.9 \\
6.1 \\
\end{array}$ \\
\hline School Effectiveness & $\begin{array}{c}\text { Institution } \\
\text { Family }\end{array}$ & $\begin{array}{l}30 \\
30 \\
\end{array}$ & $\begin{array}{l}12.07 \\
17.53 \\
\end{array}$ & $\begin{array}{l}2.9 \\
2.6 \\
\end{array}$ \\
\hline School Adjustment & $\begin{array}{c}\text { Institution } \\
\text { Family }\end{array}$ & $\begin{array}{l}30 \\
30 \\
\end{array}$ & $\begin{array}{l}13.43 \\
20.03 \\
\end{array}$ & $\begin{array}{l}3.9 \\
2.4 \\
\end{array}$ \\
\hline Emotional Competence & $\begin{array}{c}\text { Institution } \\
\text { Family }\end{array}$ & $\begin{array}{l}30 \\
30 \\
\end{array}$ & $\begin{array}{l}64.10 \\
82.30 \\
\end{array}$ & $\begin{array}{c}11.7 \\
6.5 \\
\end{array}$ \\
\hline Self-Management & $\begin{array}{c}\text { Institution } \\
\text { Family }\end{array}$ & $\begin{array}{l}30 \\
30\end{array}$ & $\begin{array}{l}21.63 \\
32.73\end{array}$ & $\begin{array}{l}5.7 \\
3.4\end{array}$ \\
\hline Emotion Management & $\begin{array}{c}\text { Institution } \\
\text { Family }\end{array}$ & $\begin{array}{l}30 \\
30 \\
\end{array}$ & $\begin{array}{l}11.23 \\
14.57 \\
\end{array}$ & $\begin{array}{l}4.0 \\
2.1 \\
\end{array}$ \\
\hline Stress Management & $\begin{array}{c}\text { Institution } \\
\text { Family }\end{array}$ & $\begin{array}{l}30 \\
30\end{array}$ & $\begin{array}{l}16.33 \\
20.07\end{array}$ & $\begin{array}{l}5.2 \\
3.5\end{array}$ \\
\hline Empathy & $\begin{array}{c}\text { Institution } \\
\text { Family }\end{array}$ & $\begin{array}{l}30 \\
30\end{array}$ & $\begin{array}{l}14.90 \\
14.93\end{array}$ & $\begin{array}{l}1.9 \\
1.6\end{array}$ \\
\hline Behavior Problems & $\begin{array}{c}\text { Institution } \\
\text { Family }\end{array}$ & $\begin{array}{l}30 \\
30 \\
\end{array}$ & $\begin{array}{l}98.27 \\
62.80 \\
\end{array}$ & $\begin{array}{l}14.4 \\
13.4 \\
\end{array}$ \\
\hline Interpersonal Adjustment & $\begin{array}{c}\text { Institution } \\
\text { Family }\end{array}$ & $\begin{array}{l}30 \\
30\end{array}$ & $\begin{array}{l}20.17 \\
20.73\end{array}$ & $\begin{array}{c}6.7 \\
10.1\end{array}$ \\
\hline Intrapersonal Adjustment & $\begin{array}{c}\text { Institution } \\
\text { Family }\end{array}$ & $\begin{array}{l}30 \\
30 \\
\end{array}$ & $\begin{array}{l}28.03 \\
30.03 \\
\end{array}$ & $\begin{array}{l}6.4 \\
9.9 \\
\end{array}$ \\
\hline Hyperactivity & $\begin{array}{c}\text { Institution } \\
\text { Family }\end{array}$ & $\begin{array}{l}30 \\
30\end{array}$ & $\begin{array}{l}39.00 \\
22.43\end{array}$ & $\begin{array}{c}10.1 \\
6.7\end{array}$ \\
\hline
\end{tabular}

Among children in institutions there were statistically significant differences between boys and girls. As it can be seen in Table 4 below, girls of this group performed better than boys in: Assertion Skills $(\mathrm{t}=-3.094, \mathrm{p}=.004)$, Interpersonal Communication $(\mathrm{t}=-3.872, \mathrm{p}=.001)$, School Adjustment $(\mathrm{t}=-2.945, \mathrm{p}=.007)$ and Self-Management $(\mathrm{t}=$ -2.552, $\mathrm{p}=.016)$. Girls, also demonstrated significantly less Behaviour Problems than institutionalized boys' ( $\mathrm{t}=2.075$, $\mathrm{p}=.048$ ). No significant differences were discovered between boys and girls for children raised in families as it concerns their psychosocial skills. 
Table 4. Institutionalized children's performances on psychosocial adjustment by gender.

\begin{tabular}{|c|c|c|c|c|}
\hline & Groups & $n$ & Mean & $S D$ \\
\hline Social Competence & $\begin{array}{l}\text { Boys } \\
\text { Girls }\end{array}$ & $\begin{array}{l}15 \\
15\end{array}$ & $\begin{array}{l}52.60 \\
53.47\end{array}$ & $\begin{array}{l}18.2 \\
18.9\end{array}$ \\
\hline Assertion Skills & $\begin{array}{l}\text { Boys } \\
\text { Girls }\end{array}$ & $\begin{array}{l}15 \\
15\end{array}$ & $\begin{array}{c}9.13 \\
13.27\end{array}$ & $\begin{array}{l}3.6 \\
3.6\end{array}$ \\
\hline Interpersonal Communication & $\begin{array}{l}\text { Boys } \\
\text { Girls }\end{array}$ & $\begin{array}{l}15 \\
15 \\
\end{array}$ & $\begin{array}{l}23.53 \\
36.33 \\
\end{array}$ & $\begin{array}{c}7.6 \\
10.2 \\
\end{array}$ \\
\hline Peer Cooperation & $\begin{array}{l}\text { Boys } \\
\text { Girls }\end{array}$ & $\begin{array}{l}15 \\
15 \\
\end{array}$ & $\begin{array}{l}10.67 \\
12.47 \\
\end{array}$ & $\begin{array}{l}4.0 \\
4.1 \\
\end{array}$ \\
\hline School Competence & $\begin{array}{l}\text { Boys } \\
\text { Girls }\end{array}$ & $\begin{array}{l}15 \\
15 \\
\end{array}$ & $\begin{array}{l}64.40 \\
73.27 \\
\end{array}$ & $\begin{array}{l}11.5 \\
13.4 \\
\end{array}$ \\
\hline Motives & $\begin{array}{l}\text { Boys } \\
\text { Girls }\end{array}$ & $\begin{array}{l}15 \\
15 \\
\end{array}$ & $\begin{array}{l}10.13 \\
10.53 \\
\end{array}$ & $\begin{array}{l}2.9 \\
1.2 \\
\end{array}$ \\
\hline Planning and Organizational Skills & $\begin{array}{l}\text { Boys } \\
\text { Girls } \\
\end{array}$ & $\begin{array}{l}15 \\
15 \\
\end{array}$ & $\begin{array}{l}31.07 \\
34.93 \\
\end{array}$ & $\begin{array}{l}4.2 \\
6.9 \\
\end{array}$ \\
\hline School Effectiveness & $\begin{array}{l}\text { Boys } \\
\text { Girls }\end{array}$ & $\begin{array}{l}15 \\
15 \\
\end{array}$ & $\begin{array}{l}11.60 \\
12.53 \\
\end{array}$ & $\begin{array}{l}3.6 \\
2.1 \\
\end{array}$ \\
\hline School Adjustment & $\begin{array}{l}\text { Boys } \\
\text { Girls }\end{array}$ & $\begin{array}{l}15 \\
15 \\
\end{array}$ & $\begin{array}{l}11.73 \\
15.13 \\
\end{array}$ & $\begin{array}{l}3.1 \\
4.1 \\
\end{array}$ \\
\hline Emotional Competence & $\begin{array}{l}\text { Boys } \\
\text { Girls } \\
\end{array}$ & $\begin{array}{l}15 \\
15 \\
\end{array}$ & $\begin{array}{l}63.60 \\
64.60 \\
\end{array}$ & $\begin{array}{c}13.7 \\
9.7 \\
\end{array}$ \\
\hline Self-Management & $\begin{array}{l}\text { Boys } \\
\text { Girls }\end{array}$ & $\begin{array}{l}15 \\
15 \\
\end{array}$ & $\begin{array}{l}18.87 \\
24.40 \\
\end{array}$ & $\begin{array}{l}6.2 \\
3.7 \\
\end{array}$ \\
\hline Emotion Management & $\begin{array}{l}\text { Boys } \\
\text { Girls } \\
\end{array}$ & $\begin{array}{l}15 \\
15 \\
\end{array}$ & $\begin{array}{l}10.60 \\
11.87 \\
\end{array}$ & $\begin{array}{l}4.6 \\
3.3 \\
\end{array}$ \\
\hline Stress Management & $\begin{array}{l}\text { Boys } \\
\text { Girls }\end{array}$ & $\begin{array}{l}15 \\
15 \\
\end{array}$ & $\begin{array}{l}16.47 \\
16.20 \\
\end{array}$ & $\begin{array}{l}6.3 \\
4.0 \\
\end{array}$ \\
\hline Empathy & $\begin{array}{l}\text { Boys } \\
\text { Girls }\end{array}$ & $\begin{array}{l}15 \\
15 \\
\end{array}$ & $\begin{array}{l}14.80 \\
15.00 \\
\end{array}$ & $\begin{array}{l}2.0 \\
1.8 \\
\end{array}$ \\
\hline Behavior Problems & $\begin{array}{l}\text { Boys } \\
\text { Girls }\end{array}$ & $\begin{array}{l}15 \\
15 \\
\end{array}$ & $\begin{array}{c}103.47 \\
93.07 \\
\end{array}$ & $\begin{array}{l}15.4 \\
11.8 \\
\end{array}$ \\
\hline Interpersonal Adjustment & $\begin{array}{l}\text { Boys } \\
\text { Girls } \\
\end{array}$ & $\begin{array}{l}15 \\
15 \\
\end{array}$ & $\begin{array}{l}19.13 \\
21.20 \\
\end{array}$ & $\begin{array}{l}7.3 \\
6.2 \\
\end{array}$ \\
\hline Intrapersonal Adjustment & $\begin{array}{l}\text { Boys } \\
\text { Girls }\end{array}$ & $\begin{array}{l}15 \\
15 \\
\end{array}$ & $\begin{array}{l}27.07 \\
29.00 \\
\end{array}$ & $\begin{array}{l}7.0 \\
5.7 \\
\end{array}$ \\
\hline Hyperactivity & $\begin{array}{l}\text { Boys } \\
\text { Girls }\end{array}$ & $\begin{array}{l}15 \\
15\end{array}$ & $\begin{array}{l}41.93 \\
36.07\end{array}$ & $\begin{array}{c}11.5 \\
7.8\end{array}$ \\
\hline
\end{tabular}

\section{DISCUSSION}

Studies conducted over the past 50 years, across the world, have documented that children raised in institutions frequently demonstrate delays in physical, emotional, social and cognitive development [2, 16, 45 - 50]. Our study suggests that Greek institutionalized children lack both language and psychosocial skills.

Specifically, according to the present study the institutionalized children had lower vocabulary skills, both expressive and receptive. They also faced many difficulties in narrative skills in comparison to children raised up in families. They made a lot of morphological errors and their syntactic structures in their narratives were simpler.

The present results confirm previous studies from other countries [9, 24, 51 - 55]. As reported by Gindis [52], by the age of 4 , about $80 \%$ of children in Russian institutions are still communicating only in one- to two-word sentences and many also have poor and insufficient vocabulary. However in some cases such language delays may be connected to medical issues (e.g., untreated otitis media), for many others these delays are most possibly associated with a restricted amount of communication and stimulation put forward by caregivers. Glennen and Masters [53] gathered parent survey information on children adopted from Eastern Europe. About $80 \%$ of the 130 children taking part exhibiting risk factors associated with difficulties in language development. Morison, Ames \& Chisholm [55] who observed 43 Romanian children roughly one year after adoption also found that most of them exhibited among other delays, language problems. Albers et al. [9] have also shown that one of five post adopted children has significant socioemotional and language delays. 
Groze and Ileana [24] found that according to the adoptive parents children adopted from Romania had among others language problems, and delayed social skills. Clauss and Baxter [51] and Judge [54] demonstrated that parents of post adopted children reported ongoing speech and language inadequacy, and social- emotional problems, which made foster parents who had adopted children from Eastern Europe, feel anxious.

\subsection{Policy Implications}

The results of the present study can have some important practical implications for policy makers and practitioners working on institutionalised children's development. Browne et al. [56, 57] have indicated that countries which invest less on public health and social services are more inclined to have increased numbers of institutionalised children, probably as a result of not providing mother and child residential care facilities or advisory services to prevent neglect and to rehabilitate parents who are at risk of mishandling or not caring their child. Locating children from institutional care into families is considered the most beneficial and important mediation possible for any human situation [58].

\section{CONCLUSION}

As discussed earlier, almost all developmental outcomes were more favourable for the children in foster care in comparison with children who had stayed behind in institutions [59]. Hence, substitute family-based care options could be encouraged for children (foster placement or adoption). De-institutionalisation is of utmost importance when it comes on establishing modern and effective care services for children and families.

\section{ETHICS APPROVAL AND CONSENT TO PARTICIPATE}

Not applicable.

\section{HUMAN AND ANIMAL RIGHTS}

No Animals/Humans were used for studies that are base of this research.

\section{CONSENT FOR PUBLICATION}

Not applicable.

\section{CONFLICT OF INTEREST}

The authors declare no conflict of interest, financial or otherwise.

\section{ACKNOWLEDGEMENTS}

Declared None.

\section{REFERENCES}

[1] Carter R. Family Matters: A study of institutional childcare in Central and Eastern Europe and the Former Soviet Union 2005.

[2] Johnson R, Browne K, Hamilton-Giachritsis C. Young children in institutional care at risk of harm. Trauma Violence Abuse 2006; 7(1): 34-60.

[http://dx.doi.org/10.1177/1524838005283696] [PMID: 16332980]

[3] Browne K, Hamilton-Giachritsis C, Johnson R, Ostergren M. Overuse of institutional care for children in Europe. BMJ 2006; 332(7539): 485-7.

[http://dx.doi.org/10.1136/bmj.332.7539.485] [PMID: 16497769]

[4] Tinova M, Browne KD, Pritchard C. Children services in Slovakia and their impact on the child's right to optimal development 2007.

[5] Zeanah $\mathrm{CH}$, Nelson CA, Fox NA, et al. Designing research to study the effects of institutionalization on brain and behavioral development: the Bucharest Early Intervention Project. Dev Psychopathol 2003; 15(4): 885-907. [http://dx.doi.org/10.1017/S0954579403000452] [PMID: 14984131]

[6] Available at: https://wearelumos.org/stories/lumos-greece

[7] Roy P, Rutter M, Pickles A. Institutional care: Risk from family background or pattern of rearing? J Child Psychol Psychiatry 2000; 41(2): $139-49$. [http://dx.doi.org/10.1017/S002196309900517X] [PMID: 10750540]

[8] Albers LH, Johnson DE, Hostetter MK, Iverson S, Miller LC. Health of children adopted from the former Soviet Union and Eastern Europe. Comparison with preadoptive medical records. JAMA 1997; 278(11): 922-4.

[http://dx.doi.org/10.1001/jama.1997.03550110060037] [PMID: 9302245] 
[9] Judge S. Developmental recovery and deficit in children adopted from Eastern European orphanages. Child Psychiatry Hum Dev 2003; 34(1): 49-62. [http://dx.doi.org/10.1023/A:1025302025694] [PMID: 14518623]

[10] Van Ijzendoorn MH, Bakermans-Kranenburg MJ, Juffer F. Plasticity of growth in height, weight, and head circumference: Meta-analytic evidence of massive catch-up after international adoption. J Dev Behav Pediatr 2007; 28(4): 334-43. [http://dx.doi.org/10.1097/DBP.0b013e31811320aa] [PMID: 17700087]

[11] Smyke AT, Dumitrescu A, Zeanah CH. Attachment disturbances in young children. I: The continuum of caretaking casualty. J Am Acad Child Adolesc Psychiatry 2002; 41(8): 972-82.

[http://dx.doi.org/10.1097/00004583-200208000-00016] [PMID: 12162633]

[12] Beckett C, Bredenkamp D, Castle J, Groothues C, O’Connor TG, Rutter M. Behavior patterns associated with institutional deprivation: A study of children adopted from Romania. J Dev Behav Pediatr 2002; 23(5): 297-303. [http://dx.doi.org/10.1097/00004703-200210000-00001] [PMID: 12394517]

[13] Rutter M, Andersen-Wood L, Beckett C, et al. Quasi-autistic patterns following severe early global privation. J Child Psychol Psychiatry 1999; 40(4): 537-49. [http://dx.doi.org/10.1111/1469-7610.00472] [PMID: 10357161]

[14] Rutter ML, Kreppner JM, O’Connor TG. Specificity and heterogeneity in children's responses to profound institutional privation. Br J Psychiatry 2001; 179: 97-103. [http://dx.doi.org/10.1192/bjp.179.2.97] [PMID: 11483469]

[15] Fisher L, Ames EW, Chisholm K, Savoie L. Problems reported by parents of Romanian orphans adopted to British Columbia. Int J Behav Dev 1997; 20: 67-82. [http://dx.doi.org/10.1080/016502597385441]

[16] MacLean K. The impact of institutionalization on child development. Dev Psychopathol 2003; 15(4): 853-84. [http://dx.doi.org/10.1017/S0954579403000415] [PMID: 14984130]

[17] Goldfarb W. Psychological privation in infancy and subsequent adjustment. Am J Orthopsychiatry 1945; 15: 247-50 [http://dx.doi.org/10.1111/j.1939-0025.1945.tb04938.x]

[18] Provence S, Lipton RC. Infants in institutions: A comparison of their development with family reared infants during the first year of life. New York: International Universities Press 1962.

[19] Dubrovina I, Ed. Psichologicheskoe razvitie vospitanikov v detskom dome. Moscow, Russia: Prosveschenie Press 1991. Psychological development of children in orphanages.

[20] Glennen S. Language development and delay in internationally adopted infants and toddlers: A review. Am J Speech Lang Pathol 2002; 11: 333-9. [http://dx.doi.org/10.1044/1058-0360(2002/038)]

[21] Windsor J, Glaze LE, Koga SF. Language acquisition with limited input: Romanian institution and foster care. J Speech Lang Hear Res 2007; 50(5): 1365-81. [http://dx.doi.org/10.1044/1092-4388(2007/095)] [PMID: 17905917]

[22] Windsor J, Benigno JP, Wing CA, et al. Effect of foster care on young children's language learning. Child Dev 2011; 82(4): 1040-6. [http://dx.doi.org/10.1111/j.1467-8624.2011.01604.x] [PMID: 21679171]

[23] Ames E. The development of Romanian orphanage children adopted to Canada (Final report to the National Welfare Grants Program: Human Resources Development Canada). Burnaby, British Columbia: Simon Fraser University 1997.

[24] Groze V, Ileana D. A follow-up study of adopted children from Romania. Child Adolesc Social Work J 1996; 13: 541-65. [http://dx.doi.org/10.1007/BF01874306]

[25] O'Connor TG, Bredenkamp D, Rutter M. Attachment disturbances and disorders in children exposed to early severe deprivation. Infant Ment Health J 1999; 20: 10-29. [http://dx.doi.org/10.1002/(SICI)1097-0355(199921)20:1<10::AID-IMHJ2>3.0.CO;2-S]

[26] Zeanah CH. Disturbances of attachment in young children adopted from institutions. J Dev Behav Pediatr 2000; 21(3): 230-6. [PMID: 10883884]

[27] Gunnar MR, Morison SJ, Chisholm K, Schuder M. Salivary cortisol levels in children adopted from romanian orphanages. Dev Psychopathol 2001; 13(3): 611-28. [http://dx.doi.org/10.1017/S095457940100311X] [PMID: 11523851]

[28] Chisholm K. A three year follow-up of attachment and indiscriminate friendliness in children adopted from Romanian orphanages. Child Dev 1998; 69(4): 1092-106. [http://dx.doi.org/10.1111/j.1467-8624.1998.tb06162.x] [PMID: 9768488]

[29] Chisholm K, Carter M, Ames E, Morison S. Attachment security and indiscriminately friendly behaviour in children adopted from Romanian orphanages. Dev Psychopathol 1995; 7: 283-94. [http://dx.doi.org/10.1017/S0954579400006507]

[30] Tizard B, Hodges J. The effect of early institutional rearing on the development of eight year old children. J Child Psychol Psychiatry 1978; 
19(2): 99-118.

[http://dx.doi.org/10.1111/j.1469-7610.1978.tb00453.x] [PMID: 670339]

[31] Tizard B, Rees J. The effect of early institutional rearing on the behaviour problems and affectional relationships of four-year-old children. J Child Psychol Psychiatry 1975; 16(1): 61-73. [http://dx.doi.org/10.1111/j.1469-7610.1975.tb01872.x] [PMID: 1123417]

[32] Zeanah CH, Smyke AT, Dumitrescu A. Attachment disturbances in young children. II: Indiscriminate behavior and institutional care. J Am Acad Child Adolesc Psychiatry 2002; 41(8): 983-9. [http://dx.doi.org/10.1097/00004583-200208000-00017] [PMID: 12162634]

[33] Beckett C, Maughan B, Rutter M, et al. Do the effects of early severe deprivation on cognition persist into early adolescence? Findings from the English and Romanian adoptees study. Child Dev 2006; 77(3): 696-711. [http://dx.doi.org/10.1111/j.1467-8624.2006.00898.x] [PMID: 16686796]

[34] Croft C, Beckett C, Rutter M, et al. Early adolescent outcomes of institutionally-deprived and non-deprived adoptees. II: language as a protective factor and a vulnerable outcome. J Child Psychol Psychiatry 2007; 48(1): 31-44. [http://dx.doi.org/10.1111/j.1469-7610.2006.01689.x] [PMID: 17244268]

[35] dosReis S, Zito JM, Safer DJ, Soeken KL. Mental health services for youths in foster care and disabled youths. Am J Public Health 2001; 91(7): 1094-9.

[http://dx.doi.org/10.2105/AJPH.91.7.1094] [PMID: 11441737]

[36] McLaughlin KA, Fox NA, Zeanah CH, Sheridan MA, Marshall P, Nelson CA. Delayed maturation in brain electrical activity partially explains the association between early environmental deprivation and symptoms of attention-deficit/hyperactivity disorder. Biol Psychiatry 2010; 68(4): 329-36. [http://dx.doi.org/10.1016/j.biopsych.2010.04.005] [PMID: 20497899]

[37] Shaw P, Eckstrand K, Sharp W, et al. Attention-deficit/hyperactivity disorder is characterized by a delay in cortical maturation. Proc Natl Acad Sci USA 2007; 104(49): 19649-54. [http://dx.doi.org/10.1073/pnas.0707741104] [PMID: 18024590]

[38] Vorria P, Papaligoura Z, Dunn J, et al. Early experiences and attachment relationships of Greek infants raised in residential group care. J Child Psychol Psychiatry 2003; 44(8): 1208-20. [http://dx.doi.org/10.1111/1469-7610.00202] [PMID: 14626461]

[39] Vorria P, Papaligoura Z, Sarafidou J, et al. The development of adopted children after institutional care: a follow-up study. J Child Psychol Psychiatry 2006; 47(12): 1246-53. [PMID: 17176379]

[40] Vorria P, Ntouma M, Vairami M, Rutter M. Attachment relationships of adolescents who spent their infancy in residential group care: The Greek Metera study. Attach Hum Dev 2015; 17(3): 257-71. [http://dx.doi.org/10.1080/14616734.2015.1028947] [PMID: 25862310]

[41] Dontas C, Maratos O, Fafoutis M, Karangelis A. Early social development in institutionally reared Greek infants: Attachment and peer interaction. Monogr Soc Res Child Dev 1985; 50(1-2): 136-46. [http://dx.doi.org/10.2307/3333830] [PMID: 4069125]

[42] Giagazoglou P, Kouliousi C, Sidiropoulou M, Fahantidou A. The effect of institutionalization on psychomotor development of preschool aged children. Res Dev Disabil 2012; 33(3): 964-70. [http://dx.doi.org/10.1016/j.ridd.2011.12.016] [PMID: 22285733]

[43] Available at: http://www.sos-villages.gr/page/english

[44] Griffiths R. The abilities of young children A comprehensive system of mental measurement for the first eight years of life. London: The Test Agency 1984.

[45] Bowlby J. Maternal care and mental health. Geneva: World Health Organization 1951.

[46] Hodges J, Tizard B. IQ and behavioural adjustment of ex-institutional adolescents. J Child Psychol Psychiatry 1989; $30(1)$ : $53-75$. [http://dx.doi.org/10.1111/j.1469-7610.1989.tb00769.x] [PMID: 2925821]

[47] Hodges J, Tizard B. Social and family relationships of ex-institutional adolescents. J Child Psychol Psychiatry 1989; $30(1)$ : $77-97$. [http://dx.doi.org/10.1111/j.1469-7610.1989.tb00770.x] [PMID: 2925822]

[48] Vorria P, Rutter M, Pickles A, Wolkind S, Hobsbaum A. A comparative study of Greek children in long-term residential group care and in two-parent families: I. Social, emotional, and behavioural differences. J Child Psychol Psychiatry 1998; 39(2): 225-36. [http://dx.doi.org/10.1017/S0021963097001996] [PMID: 9669235]

[49] Vorria P, Rutter M, Pickles A, Wolkind S, Hobsbaum A. A comparative study of Greek children in long-term residential group care and in two-parent families: II. Possible mediating mechanisms. J Child Psychol Psychiatry 1998; 39(2): 237-45. [http://dx.doi.org/10.1017/S002196309700200X] [PMID: 9669236]

[50] Wolkind S, Rutter M. Children who have been “in care”-An epidemiological study. J Child Psychol Psychiatry 1973; 14(2): 97-105. [http://dx.doi.org/10.1111/j.1469-7610.1973.tb01178.x] [PMID: 4731013]

[51] Clauss D, Baxter S. Post adoption survey of Russian and eastern European children. Belen, NM: Rainbow House International 1997. 
[52] Gindis B. Language lost, language found" experience in children adopted internationally: What are implications for school performance and family life? Paper presented at the annual meeting of Families for Russian and Ukrainian Adoption: Focus on Educational Issues for International Adoptees, Washington, DC. 2003.

[53] Glennen S, Masters MG. Typical and atypical language development in infants and toddlers adopted from Eastern Europe. Am J Speech Lang Pathol 2002; 11: 417-33. [http://dx.doi.org/10.1044/1058-0360(2002/045)]

[54] Judge SL. Eastern European adoptions: Current status and implications for intervention. Top Early Child Spec Educ 1999; 19(4): 244-67. [http://dx.doi.org/10.1177/027112149901900405]

[55] Morison SJ, Ames EW, Chisholm K. The development of children adopted from Romanian orphanages. Merrill-Palmer Q 1995; 41: 411-30.

[56] Browne KD, Hamilton-Giachritsis CE, Johnson R, et al. Mapping the number and characteristics of children under three in institutions across Europe at risk of harm (European Union Daphne Programme, Final Project Report No 2002/017/C), Birmingham, England: University Centre for Forensic and Family Psychology 2004.

[57] Browne KD, Hamilton-Giachritsis CE, Johnson R, et al. A European Survey of the number and characteristics of children less than three in residential care at risk of harm. Adopt Foster 2005; 29(4): 1-12. [http://dx.doi.org/10.1177/030857590502900405]

[58] van IJzendoorn MH, Juffer F. Adoption as intervention. Meta-analytic evidence for massive catch-up and plasticity in physical, socioemotional and cognitive development. J Child Psychol Psychiatry 2006; 47: 1228-45. [http://dx.doi.org/10.1111/j.1469-7610.2006.01675.x] [PMID: 17176378]

[59] Nelson CA III, Zeanah CH, Fox NA, Marshall PJ, Smyke AT, Guthrie D. Cognitive recovery in socially deprived young children: The Bucharest Early Intervention Project. Science 2007; 318(5858): 1937-40. [http://dx.doi.org/10.1126/science.1143921] [PMID: 18096809]

\section{(C) 2017 Ralli et al.}

This is an open access article distributed under the terms of the Creative Commons Attribution 4.0 International Public License (CC-BY 4.0), a copy of which is available at: https://creativecommons.org/licenses/by/4.0/legalcode. This license permits unrestricted use, distribution, and reproduction in any medium, provided the original author and source are credited. 